\title{
PEMANFAATAN LAHAN DAN PENGELOLAAN SUMBERDAYA HUTAN OLEH MASYARAKAT SEKITAR KAWASAN HUTAN LINDUNG GUNUNG SIRIMAU (STUDI KASUS DI DESA HUKURILA KOTA AMBON)
}

\author{
Mersiana Sahureka \\ Jurusan Kehutanan Fakultas Pertanian Universitas Pattimura Ambon \\ Jl.Ir.M.Putuhena Kampus Poka Ambon 97237 \\ Penulis Korespondensi Email : mersiana_sahureka@yahoo.com
}

Diterima : 15 Juli 2016

Disetujui : 12 Agustus 2016

\begin{abstract}
Intisari
Kehidupan sosial ekonomi dan budaya masyarakat Desa Hukurila dalam upaya pemanfaatan lahan dan pengelolaan sumber daya alam hutan untuk memenuhi kebutuhan hidup sudah merupakan kebiasaan turuntemurun yang tidak banyak menyalami perubahan. Penelitian yang dilakukan di desa Hukurila ini bertujuan untuk : 1) mengetahui karakteristik masyarakat desa Hukurila dalan pengelolaan sumber daya alam, 2. Mengetahui ragam pemanfaatan lahan oleh masyarakat Desa Hukurila 3.Mengetahui tahapan pengelolaan lahan oleh masyarakat Desa Hukurila. Dalam penelitian ini menggunakan metode survey, pemilihan dan pengambilan sampel lokasi dilakukan dengan maksud tertentu (purposeful) dengan 15 responden ditambah dengan informan kunci yakni, saniri negri (pemerintah desa) dan instransi terkait, dan LSM. Hasil penelitian menunjukan karakteristik masyrakat dalam pemanfaatn dan pengelolaan sumber daya hutan didasarkan pada kelas umur, tingkat pendidikan, jenis pekerjaan dan jumlah pendapatan. Pola pemanfaatan lahan oleh masyarakat desa Hukurila dapat dibagi menjadi 5 (lima) yakni pekarangan rumah, kebun/kabong, agroforestry dusung, hutan alam, pesisir pantai. Sedangkan tahapan pengelolaan lahan terdiri dari pesiapan, penanaman, pemeliharaan, pemanenan, pemasaran, pengolahan pasca panen.
\end{abstract}

Kata kunci : Desa Hukurila, Hutan lindung, Pemanfaatan lahan

\begin{abstract}
Socio-economic and cultural life of rural communities in an effort Hukurila land use and management of forest resources to meet the needs of life is a hereditary habits are not many greet the change. Research conducted in the village of Hukurila aims to : 1 ) determine the characteristics of rural communities Hukurila role in the management of natural resources, 2 . Knowing the diversity of land use by communities Hukurila 3.Mengetahui stages of land management by communities Hukurila. The method used is survey analysis by doing a direct observation, selection and sampling locations is done with a specific purpose ( purposeful) with 15 respondents coupled with key informants : Saniri country (village government) and related instransi , and NGO. The results showed the characteristics of the community in the utilization and management of forest resources based on age class, level of education, type of work and the amount of income. The pattern of land use by communities Hukurila can be divided into five (5) the yard, garden, Dusung agroforestry, forest, coast. While the stages of land management consists of Preparation, planting, maintenance, harvesting , marketing, post-harvest processing .
\end{abstract}

Keywords : Hukurila village, Management, Protected forest, Utilization land 


\section{PENDAHULUAN}

Pengelolaan sumber daya hutan selalu ditujukan untuk mendapatkan manfaat yang optimum. Memahami manfaat hutan, mengandung arti harus dilakukannya penilaian terhadap semua jenis manfaat yang dapat dihasilkan oleh hutan tersebut, baik yang bersifat manfaat nyata (tangible) maupun tidak nyata (intangible). Pengelolaan hutan yang dilakukan baik oleh masyarakat maupun pemerintah dan swasta tidaklah dapat dilepaspisahkan dari tujan pembangunan nasional yang berkaitan dengan dengan peningkatan kesejahteraan masyarakat. Oleh karena itu pelaksanaan pengelolaan hutan harus didasarkan pada tujuan yang ingin dicapai oleh pengelolah (semua pihak), dalam pengelolaan hutan adalah untuk memenuhi kebutuhan baik masyarakat desa hutan, serta pihak-pihak yang terkait maupun dalam mendatangkan devisa bagi negara. Oleh karena itu perlu dirumuskan secara jelas tujuan pengelolaan hutan oleh semua pihak yang terkait, yang bisa jadi berbeda satu sama lain.

Kesejahteraan masyarakat sebagai tolak ukur dari keberhasilan pengelolaan sumber daya hutan selalu dinomorsatukan walau terkadang sering mengabaikan bahkan pengorbankan lingkungan. Salah satu kawasan hutan yang mesti tetap dijaga kelestarian fungsi dan manfaatnya yakni Hutan lindung. Fungsi utama hutan lindung adalah mencegah banjir, erosi, tanah longsor terutama hutan yang berada di dataran tinggi, lereng gunung.Hutan yang berada di dataran tinggi berfungsi menyerap air hujan, agar tak langsung turun ke daerah bawah. Ada jenis pohon yang berfungsi menahan air dan mengikat tanah agar tidak longsor seperti pohon bambu, rambutan, mahoni dan masih banyak lagi.

Kawasan hutan lindung gunung Sirimau umumnya memiliki landsekap yang indah, baik pemandangan alam seperti gunung dengan jenis vegetasi dan fauna yang beragam demikian juga pemandangan pantai yang indah dengan pasir putih diselingi dengan karang-karang pantai yang menarik. Perpaduan udara gunung yang segar dan udara pantai yang hangat menambah semakin uniknya kawasan hutan lindung gunung sirimau. Disamping itu kehidupan masyarakat yang ramah dan masih memegang adat istiadat masyarakat menambah nilai bagi kawasan ini.

Umumnya masyarakat yang berada disekitar kawasan hutan lindung gunung sirimau mempunyai mata pencaharian petani yang lebih fokus pada tanaman hortikultura dan buah-buahan yang berasal dari kebun, dusung (agrofo- restry tradisional), pekarangan sehingga dikenal sebagai sumber penghasil buah bagi kota Ambon dan sekitarnya disamping berbagai hasil hutan kayu dan non kayu yang dapat diambil dari hutan. Salah satu desa yang berada di kawasan hutan lindung Sirimau yang terkenal dengan panorama alamnya yakni Desa Hukurila. Desa Hukurila memiliki beragam potensi sumber daya alam yang mesti dikembangkan demi peningkatan ekonomi dan kesejahteraan masyarakat baik potensi sumber daya alam yang ada di darat maupun di laut/perairan. Dapat dikatakan bahwa masyarakat Desa Hukurila memiliki ketergan-tungan yang tinggi terhadap keberadaan sumber daya hutan. Desa Hukurila kaya dengan potensi buah-buah yang mendorong masyarakat untuk selalu berusaha untuk melakukan intensifi-kasi kegiatan usaha tani. Selain sebagai petani, masyarakat Desa Hukurila yang memiliki petua-naan di sekitar pantai mengelolah menjadi objek-objek wisata selain itu panorama alam dibawah gunung Sirimau yang sangat indah, goa laut dan khasana budaya masyarakat setempat menyebab-kan Desa Hukurila ditetapkan sebagai salah satu desa sadar wisata di kota Ambon.

Dengan latar belakang kehidupan sosial ekonomi dan budaya masyarakat Desa Hukurila dalam upaya pemanfaatan lahan dan pengelolaan sumber daya alam hutan untuk memenuhi kebutuhan hidup sudah merupakan tradisi turuntemurun yang tidak banyak menyalami perubahan, namun pada kenyataannya ilmu pengetahuan dan teknologi selalu memberikan dampak bagi perubahan sendi-sendi kehidupan dan dari sisi lainnya masyarakat desa hutan mesti tetap mempertahankan nilai sosial budaya demi untuk keberlanjutan ekosistem hutan.

Berdasarkan uraian di atas maka penulis melakukan penelitian tentang pengelolaan sumber daya hutan oleh masyarakat di sekitar hutan lindung gunung Sirimau (Study Kasus di Desa Hukurila kota Ambon). Berdasarkan latar belakang ini maka tujuan penelitian yang akan dicapai yakni karakteristik Masyarakat Desa Hukurila dalan pengelolaan sumber daya alam, mengetahui ragam pemanfaatan lahan oleh masyarakat Desa Hukurila, mengetahui tahapan pengelolaan lahan oleh masyarakat Desa Hukurila.

\section{METODE PENELITIAN}

\section{Tempat dan Waktu Penelitian}

Penelitian dilaksanakan di Desa Hukurila yang termasuk pada kawasan Hutan Lindung Gunung Sirimau Kecamatan Leitimur selatan 
Kota Ambon dan berlangsung selama 2 bulan yakni bulan Juni-Agustus 2015.

\section{Pengambilan Data}

Dalam penelitian ini menggunakan metode survey yakni penelitian yang mengambil sampel dari satu populasi dan menggunakan kuisioner sebagai alat pengumpulan data yang pokok dan data sekunder yang menggambarkan unsur keterwakilan dari masyarakat yang terlibat dalam pengelolaan sumber daya hutan. Adapun langkah -langkah yang lazim ditempuh dalam pelaksanaan survey menurut Singarimbun (1987) adalah sebagai berikut :

1. Merumuskan masalah penelitian dan menentu-kan tujuan survey

2. Menentukan konsep dan hipotesis serta menggali kepustakaan . Adakalanya hipotesa tidak diperlukan, misalnya pada penelitian operasional

3. Pengambilan sampel

4. Pembuatan kuisioner

5. Pekerjaan lapangan, termasuk memilih dan melatih pewawancara

6. Pengolahan data

7. Analisa dan pelaporan

Pemilihan dan pengambilan sampel lokasi dilakukan dengan maksud tertentu (purposeful) berdasarkan letak desa,kelompok sosial,jumlah penduduk dan latar belakang sejarah. Desa Hukurila memiliki kondisi wilayah dan sosial ekonomi yang umumnya sangat tergantung dari hutan. Dari sampel desa kemudian diambil secara acak (random) masing-masing 15 responden ditambah dengan informan kunci yakni, saniri negri (pemerintah desa) dan instransi terkait, dan LSM. Jenis data yang dikumpulkan dalam penelitian ini, antara lain :

1. Data Primer : adalah data yang diperoleh langsung dari responden melalui interview, yakni dengan mengajukan pertanyaanpertanyaan secara langsung kepada respondens dengan menggunakan kuisioner atau pedoman wawancara, data tersebut meliputi :

- Identitas respodens,

- Aspek sosial ekonomi, aspek sosial budaya

2. Data Sekunder : adalah data lain yang diperoleh dari berbagai sumber untuk menunjang penelitian, misalnya dari instansi terkait maupun literatur pemerintah desa, kecamatan, kabupaten/kota dan propinsi, data sekunder meliputi :

- Keadaan umum lokasi penelitian, dokumen-dokumen resmi yang terkait dengan pelaksanaan program pengembangan agribisnis durian soya, keadaan masyarak-at, keadaan umum lokasi

Pengumpulan data penelitian dilakukan dengan cara :

1. Observasi dan pengamatan langsung di lapangan.Dengan membuat kunjungan langsung ke dusung yang bermanfaat untuk memberikan informasi tambahan tentang topik yang diteliti.

2. Intervieuw yakni data hasil wawancara dengan responden informan kunci dengan menggunakan kuisioner. Wawancara bertipe open-ended terkait dengan penelitian.

\section{Pengolahan dan Analisis Data}

Teknis analisis data dalam penelitian ini adalah deskriptif kualitatifdengan tujuan untuk menggambarkan fenomena tertentu secara lebih kongkrit dan terperinci.Metode teknik analisis deskriptif kualitatif adalah flow model analisis atau model analisis mengalir yang meliputi (Moleong , 1995),:

1. Data reduction, yaitu mengambil data yang diperoleh untuk melakukan analisis sedangkan data yang tidak diperlukan untuk analisis tidak diambil.

2. Data display, agar data lebih mudah untuk di mengerti maka data yang ditampilkan dalam bentuk tabel, matriks, gambar/ skema sehingga analisis yang dilakukan akan lebih akurat

3. Data Conslusion, adalah tahap penarikan kesimpulan setelah melakukan reduksi dan display terhadap data.

\section{HASIL DAN PEMBAHASAN}

\section{Karakteristik Responden}

Karakteristik responden sekitar hutan lindung diklasifikasikan berdasarkan umur responden.

\section{Kelas Umur Responden}

Umur seseorang sangat menentukan produktifitas kerja dan turut berpengaruh terhadap pengambilan keputusan terutama yang menyangkut inovasi dalam pengembangan usaha.Berikut data responden berdasarkan kelas umur dapat dilihat pada tabel 1 .

Tabel 1, memberikan gambaran bahwa 33,3 $\%$ responden di Hukurila berusia muda $(<29$ tahun), 46,6\% masih usia produktif (usia kerja) dan $20 \%$ telah lanjut usia (> 51 tahun). Sedangkan pada kelompok umur 30 - 50 tahun 
merupakan umur produktif yang umumnya telah berkeluarga sehingga lebih besar aktivitas mereka dalam pemanfaatan lahan dan pengelolaan sumber daya hutan. Untuk kelompok umur $>51$ tahun, pada usia ini seorang mulai mengurangi waktu untuk mengelolah bekerja untuk ke hutan dan hanya pengelolah dusung atau kebun dan sekitar pekarangan rumah saja.

\section{Tingkat Pendidikan}

Pendidikan dan skill merupakan modal untuk memperoleh atau meningkatkan pengetahuan dan ketrampilan. Dengan berbekal pengetahuan dan keterampilan lokal (local knowledge) niscaya seseorang dapat meningkatkan produktivitasnya dan lebih mudah menyerap perkembangan teknologi. Tingkat pendidikan responden di negeri Hukurila, tingkat pendidikan responden bervariasi mulai dari jenjang Sekolah Dasar (dulunya Sekolah Rakyat), Sekolah Menengah Tingkat Pertama, Sekolah Menengah Atas. Tingkat pendidikan responden untuk lebih jelasnya dapat di lihat pada Tabel 2 .

Tabel 2 menunjukan bahwa tingkat pendidikan responden di negeri Hukurila terdiri dari SD /SR sebanyak $33 \%$, tingkat pendidikan SMP sebanyak 13,3\% dan SMA/sederajat sebanyak 60 orang. Angka ini menunjukkan bahwa tingkat pendidikan SMA lebih dominan dipengaruhi oleh salah satu faktor berupa jarak dari desa ke ibu kota propinsi maupun kecamatan yang relative tidak terlalu jauh sehingga memper-mudah masyarakat untuk menikmati pendidikan yang layak.

Dari hasil wawancara, menunjukan respon- den yang tamatan SMA dapat dengan mudah memahami fungsi dan manfaat hutan lindung serta pemanfaatan lahan dan pengelolaan sumber daya hutan yang lestari dan berkelanjutan.

\section{Jenis Pekerjaan Responden}

Responden sebagain besar menggantungkan hidupnya pada bidang pertanian dan kebanyakan dari mereka miliki lahan garapan sendiri berupa dusung. Dusung yang mereka miliki ditanam dengan berbagai jenis tanaman baik tanaman umur panjang seperti pala dan cengkah maupun tanaman umbi-umbian seperti singkong, keladi. Jenis tanaman yang dominan ditanam yakni rambutan dan nenas. Adapun jenis pekerjaan respondens dapat dilihat pada Tabel 3 dibawah ini.

Berdasarkan tabel 3 menunjukkan bahwa masyarakat Desa Hukurila umumnya memiliki mata pencaharian sebagai petani, nelayan, wiraswasta dan PNS. Dari menunjukkan sebagain besar responden $(66,6 \%)$ berprofesi sebagai petani, $26,6 \%$ sebagai nelayan dan $6,6 \%$ seabagai pedagang/wiraswasta. Jenis tanaman yang ditanam umumnya bervariasi sesuai dengan musim. Namun mereka lebih banyak menanam singkong dan sayur-sayuran, sedangkan respondens yang lain sebagai PNS maupun pekerja swasta dan wiraswasta namun mereka tetap mengelolah lahan sebagai pekerjaan sampingan guna memenuhi kebutuhan hidup keluarga. Selain itu bagi masyarakat yang memiliki petua-nanan atau tempat tinggal di sekitar objek wisata pantai Tihulesy dan Seu mereka mengelolah.

Tabel 1. Distribusi Responden Berdasarkan Kelas Umur

\begin{tabular}{cccc}
\hline \multirow{2}{*}{ Nomor } & \multirow{2}{*}{ Umur Responden } & \multicolumn{2}{c}{ Jumlah } \\
\cline { 3 - 4 } & & Frekuensi & \% \\
\hline 1. & $30-50$ & 5 & 33,3 \\
2. & $>51$ & 3 & 46,6 \\
3. & Total & 15 & 20 \\
\hline & & & 700 \\
\hline
\end{tabular}

Tabel 2. Distribusi Respondens berdasarkan Tingkat Pendidikan

\begin{tabular}{clcc}
\hline \multirow{2}{*}{ Nomor } & Tingkat Pendidikan & \multicolumn{2}{c}{ Jumlah } \\
\cline { 3 - 4 } & Tidak tamat SR & - & Frekuensi \\
\hline 1. & SD / SR & 5 & - \\
2. & SMTP & 2 & 33,3 \\
3. & SMA/Kejuruan & 9 & 13,3 \\
4. & Perguruan Tinggi & - & 60 \\
5. & Total & 15 & - \\
\hline
\end{tabular}


Tabel 3. Distribusi Respondens Berdasarkan Jenis Pekerjaan

\begin{tabular}{cccc}
\hline \multirow{2}{*}{ Nomor } & \multirow{2}{*}{ Jenis Pekerjaan } & \multicolumn{2}{c}{ Jumlah } \\
\cline { 3 - 4 } & & Frekuensi & \% \\
\hline 1. & Pertanian & 10 & 66,6 \\
2. & Nelayan & 4 & 26,6 \\
3. & Non Pertanian & 1 & 6,6 \\
\hline & Total & 15 & 100 \\
\hline
\end{tabular}

Sumber :Data Primer, 2015

Tabel 4. Distribusi Responden Berdasarkan Pendapatan rata-rata/bulan

\begin{tabular}{clcc}
\hline \multirow{2}{*}{ Nomor } & \multirow{2}{*}{ Pendapatan Rata-rata (Rp/bulan) } & \multicolumn{2}{c}{ Jumlah } \\
\cline { 3 - 4 } & & Frekuensi & \% \\
\hline 1. & $<500.000$ & 9 & 60 \\
2. & $500.000-1.000 .000$ & 5 & 33,3 \\
3. & $>1.000 .000$ & 1 & 6,6 \\
\hline \multicolumn{2}{c}{ Total } & 15 & 100 \\
\hline
\end{tabular}

Sumber :Data Primer, 2015

4. Pendapatan Rata-rata Respondens Pendapatan keluarga berpengaruh terhadap

tingkat pemenuhan kebutuhan dasar keluarga tersebut. Pendapatan keluarga merupakan total pendapatan yang diperoleh keluarga dari berbagai sumber pendapatan baik pertanian maupun non pertanian (dagang, jasa, pertukangan dan pegawai negri dan swasta, wiraswasta). Pendapatan ratarata responden dapat dilihat pada rincian mulai dari pendapatan rendah < Rp 500.000/bulan, pendapatan sedang Rp 500.000 - 1.000.000/bulan dan pendapatan tinggi $\mathrm{Rp}>1.000 .000 /$ bulan dan dapat dilihat pada Tabel 4 .

Berdasarkan tabel 4, terlihat bahwa sebagian besar responden $(60 \%)$ memiliki pendapatan rendah yaitu < Rp 500.000 /bulan diikuti, dengan $33,3 \%$ berpendapatan sedang Rp 500.000 - Rp 1.000.000/bulan dan 6,6\% berpendapatan tinggi $>$ Rp 1 juta/ bulan. Besarnya pendapatan ini dipengaruhi oleh jenis pekerjaan yang digeluti. Jenis pekerjaan yang berkaitan langsung dengan kegiatan wisata yang dilakukan seperti penjual kue, pemilik kios mereka sangat merasakan dampak ekonomi dari pengembangan desa wisata ini.

Luasnya dusung yang dimiliki oleh respondens dan tingkat keragaman jenis yang ditanam turut mempengaruhi pendapatan masyarakat. Misalnya dusung yang ditanami beberapa jenis tanaman semusim dapat dipanen setiap saat secara bergiliran dan berkesinam-bungan dengan jenis yang lain sehingga dapat menjamin kebutuhan dan ketahanan pangan keluarga. Sedangkan cengkeh (Eugenia aromatica) dan pala (Myristica fragrans) responden harus menunggu musim panen satu tahun sekali. Biasanya hasil panen dijual untuk kebutuhan sekolah anak. Dengan demikian dusung dapat bermanfaat sebagai tabungan jangka panjang bagi keluarga dan dapat meme-nuhi kebutuhan jangka pendek, menengah maupun panjang.

\section{Keanekaragaman Flora dan Fauna}

Potensi keanekaragaman hayati yang ada di Desa Hukurila meliputi flora dan fauna. Hasil pengamatan lapangan menunjukkan bahwa jenis vegetasi dominan pada tingkat pohon didominasi oleh jenis tanaman umur panjang seperti cengkeh (Aromatic asp), pala (Myristica fragrans), durian (Durio zibethinus), kenari (Canarium $s p$ ) sedangkan jenis tanaman buah-buahan seperti manga (Mangifera indica), sukun, alpokat, jambu. Untuk tingkat tiang didominasi oleh jenis tanaman buah-buahan seperti langsat (Lansium domesticum), pala, cempedak, Duku (Lansium sp), kakusang, sirsak, lacing. Tingkat sapihan didominasi oleh jenis langsat, durian, cempedak, pala (Myristica fragrans), rambutan, ketapang (Terminalia cattapa), jambu biji, sukun, alpokat dan tingkat semai didominasi oleh jenis kelapa (Cocos nucifera), lenggua (Pterocarpus indicus), gaharu, jeruk (Citrus sp) dan pisang.

Jenis fauna yang dijumpai umumnya jenis burung seperti burung Nuri raja (Alisteris 
ambonensis), Perkicit (Triholousus spp), Maleo (Macrocephalon maleo), Raja udang (Halcyon soneta), Pombo (Ducula becolor). Selain itu juga dijumpai Kus-kus (Phalanger orientalis), Babi hutan (Sus crova), dan kelelawar (Pteropus vampirus).

\section{Pola Pemanfaatan Lahan oleh Masyarakat}

Berdasarkan pola pemanfaatan lahan oleh masyarakat Desa Hukurila dapat dibagi menjadi 5 (lima) yakni :

1. Pekarangan rumah : merupakan lahan yang berada disekitar rumah yang dalam pengelolaannya dilakukan oleh pemilik rumah. Pada model ini yakni pekarangan dimanfaatkan oleh masyarakat untuk menanaman sayur-sayuran dan pohon buahan -buahan seperti rambutan namun hanya beberapa pohon saja. Jika pekarangan rumah masih luas maka ditanami dengan umbi-umbian seperti singkong.

2. Kebun/Kabong : merupakan lahan yang berada tidak jauh dari rumah dan dalam pemanfaatnya biasanya tanami dengan satu atau 2 jenis tanaman seperti nenas, atau umbi-umbian yakni singkong

3. Agroforestry Dusung : merupakan bentuk pengelolaan lahan yang ditanami dengan tanaman pertanian maupun tanaman kayukayuan.Umumunya letak dusung ini agak jauh dari tempat tinggal masyarakat sekitar 30-60 menit perjalanan. Pola tanam adalah kombinasi annual, perennial dan forests crops yang menjamin kebutuhan jangka pendek menengah dan panjang. Kombinasi tanaman yang ada di dusung seperti : cengkeh, pala dikombinasikan dengan tanaman singkong sebagai tanaman cela dan juga buah-buahan kebanyak yang ditanam yakni nenas dan rambutan, langsat, duku, durian.

4. Hutan alam : hutan alam letaknya jauh dari pemukiman dengan demikian masyarakat tidak terlalu sering ke hutan hanya jika ada kebutuhan misalnya untuk mangambil bambu. Biasanya untuk membuka dusung yang baru, awalnya masyarakat mengelolah hutan alam ini yang nantinya akan menjadi dusung setelah ditanam beberapa tahun 2-4 tahun mereka akan pindah ke lokasi lain dan dusung tersebut akan menjadi "ewang' bekas lahan.

5. Pesisir pantai : Desa Hukurila merupakan salah satu desa sadar wisata di kota Ambon, maka bagi masyarakat yg memiliki petuanan di sekitar daerah pesisir pantai. Bagi masyarakat terutama bagi respondens yang memi- liki lahan sekitar daerah pantai seperti pantai Tihulessy, pantai Seu mereka sangat merasakan dampak dari pengembangan Desa Hukurila sebagai desa wisata namun sayang-nya mereka masih mempermasalahkan status kepemikikan lahan/lokasi wisata agar tetap dikelolah oleh masing-masing pemilik dengan mendapatkan dana dari pemerintah atau dengan kata lain mereka enggan untuk memberikan lahan/lokasi untuk dikelolah oleh pemerintah. Hal ini menjadi hambatan untuk pengembangan ekowisata di negeri Hukurila yang setidaknya membutuhkan waktu panjang untuk melakukan pendekatan personal dengan pemilik maupun juga dengan pemerintah negeri.

\section{Kearifan Lokal Masyarakat dalam Pengelo- laan Sumber Daya Hutan}

Desa Hukurila merupakan salah satu Adat di Kota Ambon.Sebagai desa adat kehidupan masyarakat masih sarat dengan kegiatan yang berhubungan dengan adat istiadat yang berlaku dan dipegang secara turun temurun.Kehidupan antar masyarakat masih terjalin dengan baik dalam hal hubungan sosial maupun keagamaan. Berbagai permasalahan yang terjadi dalam membangun hubungan antar masyarakat dilakukan secara musyawarah untuk mufakat dan difasilitas oleh lembaga adat desa yang sering disebut "tiga batu tungku" yaitu saniri negeri dan raja, pendeta dan guru. Aspek pemerintahan, keagamaan dan pendidikan menjadi satu kesatuan yang saling mendukung dalam mem-bangun hubungan kemasyarakatan. Salah satu kegiatan sosial dan kebersamaan yang dilakukan yakni tradisi kerja masohi yang merupakan budaya gotong-royong yang masih tetap dipertahankan oleh masyarakat, misalnya dalam pengelolaan dusung/kebun dan proses pembang-unan rumah warga.

Pengelolaan dusung oleh masyarakat Desa Hukurila telah berlangsung terun-temurun. Begitu pula dengan aturan dan kaidah yang dibuat baik secara lisan maupun tertulis yang mengatur masyarakat dalam penge-lolaan sumber daya alam untuk tetap menjaga kelestarian hasil maupun ekosistem. Aturan/ kaidah tersebut yakni pelaksanaan sasi yaitu larangan untuk mengambili hasil dusung/kebun sebelum masak panen atau waktu yang telah ditentukan secara bersama. Sasi di negeri Hukurila terdiri dari 2 yakni sasi negeri (sasi adat) dan sasi gereja. Sasi Negeri biasanya diterapkan dan dipantau lang-sung oleh saniri negeri khususnya kewang yang mempunyai tugas dan tanggungjawab terkait 
dengan pelestarian sumber daya alam. Kewang Laut bertugas menjaga memantau pe-manfaatan dan pengelolaan sumber daya alam yang ada di laut sedangkan kewang darat bertugas untuk memantau pemanfaatan dan pengelolaan sumber daya alam yang ada di darat. Sasi gereja dilaksanakan dengan terlebih dahulu mendoakan tanaman yang hendak disasi dalam ibadah minggu oleh pendeta di gereja. Hingga saat ini pelaksanaan sasi masih sering dilakukan namun lebih yang diterapkan pelaksaan sasi gereja. Jenis tanaman yang umumnya di sasi yaitu kelapa sedangkan jenis tanaman lain seperti buahbuahan seperti durian, langsat, rambutan, nenas biasanya akan dilakukan sasi atas permintaan pemilik lahan.

\section{Tahapan Pengelolaan Sumberdaya Hutan pada Lahan Dusung}

Dalam pengelolaan sumber daya hutan khususnya yang berada di dalam suatu lahan dusung, biasanya dikelolah secara turun-temurun dari generasi ke generasi untuk menjamin kehidupan. Adapun tahapan pengelolaan dusung sebagai berikut : Adapun tahapan pengelolaan dusung adalah sebagai berikut :

Tahap 1. Persiapan. Kegiatan masyarakat desa Hukurila dalam mengelolah dusung biasanya diawali dengan mencari dan menentukan Penentuan lokasi lahan yang akan ditanam biasanya disesuaikan dengan jenis yang akan ditanam. Selanjutnya pohon ditebang/ditebas dan dilakukan pembersihan semak-belukar dan liana sedangkan beberapa pohon besar dibiarkan tumbuh sebagai pelindung. Luas lahan biasanya tergantung dari tujuan pengelolahan. Selanjutnya pohon, liana dan semak belukar yang telah kering kemudian dikumpulkan dan dibakar dengan tujuan untuk memudahkan proses penanaman. Untuk menjaga agar api tidak merembes ke lahan milik orang lain maka pemilik lahan dibantu oleh keluarga, mereka juga telah mengerti tentang aturan yang berlaku, biasanya membakar lahan dilakukan pada pagi hari saat angin tidak terlalu kencang dan mereka akan selesai dan pulang ke rumah jika api telah padam. Jika hari pertama proses pembakaran belum rampung maka dilanjutkan pada hari berikutnya. Lahan yang telah selesai dibakar sisa -sisa ranting pohon dan semak-belukar yang tidak terbakar dikumpul kemudian di bakar kembali dan tanahnya digemburkan untuk siap ditanam.

Tahap 2. Penanaman. Tahap penanaman biasanya dilakukan pada awal musim hujan. Jenis tanaman yang akan ditanam di dusung disesuaikan dengan kondisi kesesuaian lahan dan juga kebutuhan masyarakat serta pemeliharaan. Pola tanam di dusung umumnya merupakan pola tanam ganda yakni pada satu areal ditanam berbagai jenis tanaman yang merupakan kombinasi tanaman setahun/umur pendek (annual crops), tanaman tahunan (perennial crops) dan tanaman kehutanan (forest crops) dan tidak menggunakan pengaturan jarak tanam. Tanaman hanya ditanam di sela-sela tanaman lain atau diantara batu-batu. Pada awal tanam (terbentuknya dusung baru) ditanam dengan tanaman umur pendek berulang-ulang selama 1-3 tahun selanjutnya ditanami dengan tanaman umur panjang.

Tahap 3. Pemeliharaan. Tahapan pemeliha-raan dilakukan setelah penanaman yakni pember-sihan (penyiangan) tanaman bawah dengan cara mencabut rumput, liana dan semak belukar yang tumbuh diantara tanaman pokok dengan tujuan untuk memberi ruang tumbuh bagi tanaman. Masyarakat lebih cenderung untuk melakukan penyiangan di dusung yang ditanami dengan tanaman pangan sedang untuk tanaman umur panjang seperti cengkeh dan durian, penyiangan dilakukan saat menjelang musim panen agar mempermudah proses pemanenan. Selain penyiangan juga dilakukan pendangiran yakni menggemburkan tanah untuk merangsang pertumbuhan tanaman.

Tahap 4. Pemanenan. Setiap tanaman memiliki umur panen yang berbeda. Proses pemanenan dilakukan pada saat tanaman mencapai umur masak panen yang ditandai dengan sifat fisik tanaman yakni warna dan bau. Saat musim panen tiba, masyarakat memilih untuk tinggal di dusung di rumah kebun (walang) untuk mengumpulkan dan menjaga hasil panen. Masyarakat juga mempunyai suatu kebiasaan untuk membagikan hasil dusung kepada tokoh agama (pendeta) maupun pemerintah desa dan sanak keluarga juga tetangga. Mengingat banyak jenis yang ditanam di dusung maka proses pemanenan yang dilakukan juga berkesimbangan antara panen tanaman yang satu dengan yang lain. Hal ini membuat masyarakat tidak berkeku-rangan dalam memenuhi kebutuhan pangan sedangkan untuk pemanenan pohon (tanaman kehutanan) hanya saat dibutuhkan saja (tebang butuh) untuk kebutuhan membangun rumah dan membuat perahu.

Tahap 5. Pemasaran. Hasil dusung yang telah dipanen kemudian dipikul dan dibawa pulang ke rumah untuk dikomsumsi bersama anggota keluarga lainnya dan jika ada kelebihan, baru dijual. Harga untuk setiap tanaman hasil 
dusung disesuaikan dengan ukuran dan kualitas. Biasanya sebelum menjual hasil masyarakat terlebih dulu memilah-milah mana yang harus dikomsumsi dan mana yang harus di jual. Setelah memilah-milah hasil panen maka secara perorangan menjual ke kota ataupun pasar lokal. Biasanya kegiatan pemasaran lebih banyak didominasi oleh kaum ibu.

Tahap 6. Pengolahan pasca panen. Setelah pemanenan, selanjutnya masyarakat dengan cara yang masih sangat sederhana hasil dusung tersebut diolah. Umumnya pengelolahan hasil dusung pasca panen untuk pengawetan buahbuahan belum banyak dilakukan oleh masyarakat karena jika musim panen mereka hanya memanen secukupnya sesuai kebutuhan. Sedangkan untuk lahan dusung sendiri dibiarkan begitu saja sekitar dan akan kembali ditanam kembali hingga 2-3 tahun kemudian masyarakat akan berpindah ke lahan lain dan lahan yang pertama akan dibiarkan begitu saja (masa berra).

Pengelolaan pasca panen masih dilakukan secara tradisional dan belum ada penerapan teknologi modern yang sesuai dengan kondisi masyarakat kerena keterbatasan informasi dan pengetahuan masyarakat. Dengan demikian perlu dikemas proses bimbingan dan pelatihan tentang teknik pengelolaan pasca panen dengan teknologi bersifat adaptif.

\section{KESIMPULAN}

1. Pola pemanfaatan lahan oleh masyarakat Desa Hukurila terdiri dari pemanfaatan lahan pekaranga, kebun/kabong, dusung, hutan alam, dan pesisir pantai

2. Pengelolaan dusung oleh masyarakat di Desa Hukurila diawali dengan menentukan lokasi, persiapan (penebangan/penebasan), pembersihan sisa tebangan dan pembakaran, penanaman, pemeliharaan (penyiangan, pembersihan gulma), pemanenan, pemasa-ran dan pengelolaan pasca panen.

\section{DAFTAR PUSTAKA}

Anonim, 2006. Laporan Kegiatan Pelaksanaan dan Pemeliharaan Hutan Rakyat, Dinas Kehutanan Pertanian dan Peternakan Kota Ambon

Ajawailla, J.W. 1996. Potensi Sosial Budaya Agroforestry Dusung. Pusat Studi Maluku, Universitas Pattimura Ambon

Ambar, T, 2004.Kemitraan dan Model-model Pemberdayaan, Penerbit Gava Media
Awang S, Andayani W, Himmah B, Widayanti W, Affianto. 2002, Hutan Rakyat Sosial Ekonomi dan Pemasaran, BPFE- Yogjakarta

Fandeli Chafid, 1999. Teknik Pengelolaan Objek Wisata Alam. Jurusan Konservasi Sumberdaya Hutan Fakultas Kehutanan UGM.

Franz, J.J.1993. Pola Dusung Salah Satu Alternatif Pengelolaan Sumber Daya Hutan di Maluku. Makalah disampaikan pada Seminar Pertanian Kepulauan. Fakultas Pertanian Universitas Pattimura Ambon

Sahureka, M, 2009. Pengelolaan dan Pengem-bangan Hutan Rakyat di Desa Soya dan desa Tariwi di Kota Ambon (Thesis, tidak dipubilkasikan)

Suharto, E, 2005. Membangun Masyarakat Memberdayakan Rakyat, Refika Aditama Bandung

Suparjan dab Hempri S, 2003. Pengembangan Masyarakat (Dari Pembangunan Sampai Pemberdayaan) Aditya Media Yogyakarta

Sunartiningsih, A, 1994 . Pemberdayaan Masyarakat Melalui Institusi Lokal, Aditya Media Yogjakarta 